University of Nebraska - Lincoln

DigitalCommons@University of Nebraska - Lincoln

2015

\title{
Toxicity reference values for chlorophacinone and their application for assessing anticoagulant rodenticide risk to raptors
}

\author{
Barnett A. Rattner \\ United States Geological Survey, brattner@usgs.gov \\ Katherine E. Horak \\ U.S. Department of Agriculture, katherine.e.horak@aphis.usda.gov \\ Rebecca S. Lazarus \\ U.S. Geological Survey \\ Sandra L. Schultz \\ U.S. Geological Survey \\ Susan Knowles \\ U.S. Geological Survey
}

See next page for additional authors

Follow this and additional works at: https://digitalcommons.unl.edu/usgsstaffpub

Part of the Geology Commons, Oceanography and Atmospheric Sciences and Meteorology Commons, Other Earth Sciences Commons, and the Other Environmental Sciences Commons

Rattner, Barnett A.; Horak, Katherine E.; Lazarus, Rebecca S.; Schultz, Sandra L.; Knowles, Susan; Abbo, Benjamin G.; and Volker, Steven F., "Toxicity reference values for chlorophacinone and their application for assessing anticoagulant rodenticide risk to raptors" (2015). USGS Staff -- Published Research. 956.

https://digitalcommons.unl.edu/usgsstaffpub/956

This Article is brought to you for free and open access by the US Geological Survey at DigitalCommons@University of Nebraska - Lincoln. It has been accepted for inclusion in USGS Staff -- Published Research by an authorized administrator of DigitalCommons@University of Nebraska - Lincoln. 


\section{Authors}

Barnett A. Rattner, Katherine E. Horak, Rebecca S. Lazarus, Sandra L. Schultz, Susan Knowles, Benjamin G. Abbo, and Steven F. Volker 


\title{
Toxicity reference values for chlorophacinone and their application for assessing anticoagulant rodenticide risk to raptors
}

\author{
Barnett A. Rattner · Katherine E. Horak • \\ Rebecca S. Lazarus • Sandra L. Schultz • \\ Susan Knowles • Benjamin G. Abbo • \\ Steven F. Volker
}

Accepted: 6 January 2015/Published online: 20 January 2015

(C) Springer Science+Business Media New York (outside the USA) 2015

\begin{abstract}
Despite widespread use and benefit, there are growing concerns regarding hazards of second-generation anticoagulant rodenticides to non-target wildlife which may result in expanded use of first-generation compounds, including chlorophacinone (CPN). The toxicity of CPN over a 7-day exposure period was investigated in American kestrels (Falco sparverius) fed either rat tissue mechanically-amended with CPN, tissue from rats fed Rozol ${ }^{\circledR}$ bait (biologically-incorporated CPN), or control diets (tissue from untreated rats or commercial bird of prey diet) ad libitum. Nominal CPN concentrations in the formulated diets were $0.15,0.75$ and $1.5 \mu \mathrm{g} / \mathrm{g}$ food wet weight, and measured concentrations averaged $94 \%$ of target values. Kestrel food consumption was similar among groups and body weight varied by less than $6 \%$. Overt signs of intoxication, liver CPN residues, and changes in prothrombin time (PT), Russell's viper venom time (RVVT) and hematocrit, were generally dose-dependent. Histological evidence of hemorrhage was present at all CPN dose
\end{abstract}

Electronic supplementary material The online version of this article (doi:10.1007/s10646-015-1418-8) contains supplementary material, which is available to authorized users.

B. A. Rattner $(\bowtie) \cdot$ R. S. Lazarus · S. L. Schultz

U.S. Geological Survey, Patuxent Wildlife Research Center,

BARC East-Building 308, 10300 Baltimore Avenue, Beltsville,

MD 20705, USA

e-mail: brattner@usgs.gov

K. E. Horak · B. G. Abbo · S. F. Volker

U.S. Department of Agriculture, Animal and Plant Health

Inspection Service, National Wildlife Research Center,

Fort Collins, CO 80521, USA

S. Knowles

U.S. Geological Survey, National Wildlife Health Center,

Madison, WI 53711, USA levels, and most frequently observed in pectoral muscle and heart. There were no apparent differences in toxicity between mechanically-amended and biologically-incorporated CPN diet formulations. Dietary-based toxicity reference values at which clotting times were prolonged in $50 \%$ of the kestrels were $79.2 \mu \mathrm{g}$ CPN consumed $/ \mathrm{kg}$ body weight-day for PT and $39.1 \mu \mathrm{g} / \mathrm{kg}$ body weight-day for RVVT. Based upon daily food consumption of kestrels and previously reported CPN concentrations found in small mammals following field baiting trials, these toxicity reference values might be exceeded by free-ranging raptors consuming such exposed prey. Tissue-based toxicity reference values for coagulopathy in $50 \%$ of exposed birds were $0.107 \mu \mathrm{g}$ CPN/g liver wet weight for PT and $0.076 \mu \mathrm{g} / \mathrm{g}$ liver for RVVT, and are below the range of residue levels reported in raptor mortality incidents attributed to CPN exposure. Sublethal responses associated with exposure to environmentally realistic concentrations of CPN could compromise survival of free-ranging raptors, and should be considered in weighing the costs and benefits of anticoagulant rodenticide use in pest control and eradication programs.

Keywords American kestrel - Anticoagulant rodenticide $\cdot$ Birds $\cdot$ Clotting time $\cdot$ Non-target effects . Risk assessment $\cdot$ Secondary poisoning

\section{Introduction}

The control of commensal vertebrate pests in agricultural, suburban and urban settings has been dependent on the use of anticoagulant rodenticides (ARs) for over 50 years. Second-generation ARs (principally brodifacoum) have played a central role in the eradication of invasive 
vertebrate pests in more than 700 island ecosystem restoration projects during the past 30 years (Howald et al. 2007; Island Conservation 2012). Many reports describe exposure and unintentional mortality of birds and mammals (reviewed in Rattner et al. 2014b), although there is no definitive evidence of large-scale population declines in predatory and scavenging wildlife. It has been suggested that ARs are an additional mortality factor affecting populations that are experiencing critical limitations (Brakes and Smith 2005). In a probabilistic assessment of 270 raptors found dead, at least $11 \%$ of the great horned owls (Bubo virginianus) analyzed were at risk of being directly killed by second-generation ARs (SGARs; bromadiolone, brodifacoum, difethialone) (Thomas et al. 2011). In much of North America, the recent restrictions placed on the use of SGARs (Health Canada 2012; USEPA 2012), are likely to result in expanded use of first-generation ARs (FGARs). In Europe SGARs continue to be the mainstay of rodent control (reviewed in Rattner et al. 2014b).

Chlorophacinone (CPN) is a FGAR that has been used worldwide for the control of commensal rodents, principally in agricultural and urban settings. It has been found in liver tissue of non-target birds in various monitoring and forensic investigations (Berny et al. 1997; Stone et al. 2003; Albert et al. 2010; Hughes et al. 2013; Vyas et al. 2013). There have been some secondary exposure incidents in which the death of raptors (bald eagle Haliaeetus leucocephalus; barn owl Tyto alba; ferruginous hawk Buteo regalis; great horned owl) was attributed to CPN exposure (Berny et al. 1997; USEPA 2011a, 2012; USFWS 2012). Acute oral and short-term dietary toxicity studies in Northern bobwhite (Colinus virginianus) in support of CPN registration categorize this FGAR as being moderately to highly toxic to birds (USEPA 2011a). Small-scale studies with captive raptors fed $\mathrm{CPN}$-exposed rodents have described sublethal effects including hemorrhage, prolonged clotting time (coagulopathy), and other signs of intoxication, but not mortality (Mendenhall and Pank 1980; Radvanyi et al. 1988; Riedel et al. 1988; Askham and Poché 1992; Salim et al. 2014). In these studies, both Mendenhall and Pank (1980) and Salim et al. (2014) attempted to estimate CPN exposure of barn owls fed poisoned rats (Rattus norvegicus, $R$. rattus and $R$. tiomanicus) based on uneaten rodent remains and analyses of excrement and castings. However, actual CPN concentration in poisoned rats was not quantified, and thus dietary dose was a rough approximation at best. Remarkably, none of these studies quantified CPN residues in liver, the principal tissue used in $\mathrm{AR}$ forensic investigations in wildlife and the major site of vitamin $\mathrm{K}$ recycling needed for clotting factor carboxylation in hemostasis. Data on dose and tissue residues are necessary in the development of toxicity thresholds for adverse effects and to assess risk.
In the present study, we examined the toxicity of CPN in American kestrels (Falco sparverius), a species often selected as a model for raptorial birds (reviewed in Bardo and Bird 2009), and recently found to be considerably more sensitive to the FGAR diphacinone than traditionally tested avian wildlife species (Northern bobwhite; mallards, Anas platyrhynchos) (Rattner et al. 2011, 2012a, b). Graded doses of CPN that had either been mechanically-amended into rat tissue or biologically-incorporated into rat tissue were fed to kestrels, and measurements of food intake and tissue CPN residues were used to generate toxicity reference values for coagulopathy and examine thresholds for other toxicological effects. The inclusion of two dietary forms of CPN (i.e., mechanically-amended and biologically-incorporated) was undertaken to address potential toxicological effects related to the presence of metabolites and differences in bioavailability. With the likelihood that FGAR use will continue, and perhaps even increase in the near future, these and other data were incorporated into assessments to more completely evaluate the risk of CPN to predatory birds.

\section{Materials and methods}

\section{Animals}

Procedures involving animals were reviewed and approved by the Institutional Animal Care and Use Committees of the Patuxent Wildlife Research Center and the National Wildlife Research Center. Adult 2- to 3-year old American kestrels, propagated from the colony at Patuxent (Porter and Wiemeyer 1970), were transferred from flight pens to small cages $(1.2 \mathrm{~m}$ long $\times 0.8 \mathrm{~m}$ wide $\times 0.6 \mathrm{~m}$ high $)$ with a shade roof, perches, food tray and water bowl. Only male birds were used, due in part to their availability from the colony and potentially confounding effects of egg-laying in reproductively active females. Individually housed kestrels $(n=40)$ were acclimated to pens for several weeks (March and April 2013), and were fed dead chicks (Gallus domesticus) or mice (Mus musculus; Charles River Laboratories, Germantown, MD fed Purina 5L79 rodent chow containing $3.4 \mathrm{ppm}$ dry weight vitamin $\mathrm{K}$ ). Two weeks prior to the exposure trial, a $0.9 \mathrm{ml}$ jugular venipuncture sample was collected into $0.1 \mathrm{ml}$ of $3.2 \%$ sodium citrate (Sigma-Aldrich, St. Louis, MO) from each bird. Microhematocrit was determined, and the remainder of each blood sample was centrifuged at $2000 \times g$ for $5 \mathrm{~min}$. Citrated plasma was harvested and divided among 3 cryovials stored at $-80{ }^{\circ} \mathrm{C}$ for subsequent determination of baseline clotting time. Kestrels were then fed Classic Bird of Prey diet (Nebraska Brand, North Platte, NE containing $2.63 \mathrm{ppm}$ dry weight vitamin K) supplemented with 
Vionate $^{\circledR}$ (Gimborn US, Atlanta, GA) for 11 days, after which 35 birds were shifted to a diet of ground rat tissue (see section on diet preparation) and 5 were maintained on Classic Bird of Prey diet. The CPN toxicity study was conducted between April 10 and 18, 2013 (ambient temperature: $6.7-32.2{ }^{\circ} \mathrm{C}$ ), with the initial body weight (mean $\pm \mathrm{SD}$ ) of kestrels being $104.0 \pm 7.23 \mathrm{~g}$.

Commercially available adult SAS Sprague-Dawley outbred rats (Rattus norvegicus, $\mathrm{n}=63$ males and 63 females weighing 220-225 g; Charles River Laboratories, Portage, MI) were used to prepare test diets for the kestrels. Rats were group housed ( $\mathrm{n}=7-15$, segregated by sex) in large tanks (size range: $89 \mathrm{~cm}$ long $\times 57 \mathrm{~cm}$ wide $\times$ $58 \mathrm{~cm}$ high to $179 \mathrm{~cm}$ long $\times 64 \mathrm{~cm}$ wide $\times 61 \mathrm{~cm} \mathrm{high),}$ and provided food (Purina 5001 laboratory rodent diet containing $1.3 \mathrm{ppm}$ dry weight vitamin $\mathrm{K}$ ) and water ad libitum for a 1-week acclimation period.

Preparation of diets

Several diets were prepared for the CPN feeding trial. The food for one control group consisted of commercially available Classic Bird of Prey diet formed into $25.0 \pm 0.1 \mathrm{~g}$ wet weight meatballs. The diet of a second control group was tissue from untreated laboratory rats euthanized with carbon dioxide. Briefly, fur, paws, tail, gastrointestinal tract and skull were removed from carcasses, and the remaining tissue was ground, forced through a 3/16 inch extrusion plate and drained of excess fluid using cheese cloth. This ground tissue (hereafter RT) was amended with $15 \mathrm{ml}$ vegetable oil/kg RT and formed into $18.0 \pm 0.1 \mathrm{~g}$ wet weight meatballs.

Three diets containing biologically-incorporated CPN were prepared from rats $(n=35$, mixed sexes) that had been provided no choice ad libitum access to Rozol ${ }^{\circledR}$ bait $(0.005 \%$ CPN; Liphatech, Inc., Milwaukee, WI) for 3 days, and then euthanized. Ground tissue from CPN-fed rats (fur, paws, tail, gastrointestinal tract and skull removed) was chemically analyzed by reversed phase ionpaired high-performance liquid chromatography (methods described below) and found to contain about $1.5 \mu \mathrm{g} \mathrm{CPN} / \mathrm{g}$ wet weight. This tissue was mixed with varying quantities of untreated RT to yield nominal concentrations of 0.15 and $0.75 \mu \mathrm{g} \mathrm{CPN} / \mathrm{g}$. Each of these diets was amended with $15 \mathrm{ml}$ vegetable oil $/ \mathrm{kg}$ tissue to maintain constant caloric content used in the mechanically-amended diets, and then formed into $18.0 \pm 0.1 \mathrm{~g}$ wet weight meatballs.

Based upon concentrations used for the biologicallyincorporated CPN diets, three concentration-matched mechanically-amended CPN diets were prepared from RT. Neat CPN was dissolved in acetone, and then added to vegetable oil (1:20). Varying quantities of this solution were mixed into RT and additional vegetable oil was added to maintain constant caloric content (total of $15 \mathrm{ml} / \mathrm{kg} \mathrm{RT}$ ). Nominal CPN concentrations in these diets were $0.15,0.75$ and $1.5 \mu \mathrm{g} / \mathrm{g}$ RT wet weight, and $18.0 \pm 0.1 \mathrm{~g}$ wet weight meatballs were formed for use in the feeding trial.

The 2 control diets, 3 mechanically-amended CPN diets, and 3 biologically-incorporated CPN diets were supplemented with Vionate ${ }^{\circledR}$ and meatballs were stored frozen at $-10{ }^{\circ} \mathrm{C}$. Moisture content (mean $\pm \mathrm{SD}$ ) of the Classic Bird of Prey control diet, RT control diet, 3 mechanicallyamended CPN diets, and the 3 biologically-incorporated CPN diets were $63.0 \pm 1.1,70.1 \pm 0.5,69.0 \pm 0.4$ and $69.0 \pm 0.9 \%$, respectively.

\section{Chlorophacinone toxicity trial in American kestrels}

One control group ( $\mathrm{n}=5$ kestrels) was fed Classic Bird of Prey meatballs throughout the course of the study, and another control group $(\mathrm{n}=5)$ was fed untreated RT meatballs for 3 days prior to the study and also during the course of the 7-day toxicity trial. These two control diets were used to determine if there were any differences in feeding Classic Bird of Prey (two $25 \mathrm{~g}$ meatballs/day) or RT (two $18 \mathrm{~g}$ meatballs/day) on measurement endpoints.

Kestrels in the six CPN treatment groups ( $\mathrm{n}=5$ /group) were fed untreated RT meatballs for 3 days prior to the study, and then received either mechanically-amended or biologically-incorporated diets for the 7-day exposure period. Birds were fed daily between 1200 and $1300 \mathrm{~h}$, and uneaten food scraps were collected from kraft paper-lined pens the following day between 1000 and $1200 \mathrm{~h}$. The scraps for each kestrel during the exposure period were pooled, weighed, stored frozen at $-10{ }^{\circ} \mathrm{C}$, dried at $100{ }^{\circ} \mathrm{C}$ for $24 \mathrm{~h}$ and mathematically converted back to wet weight as previously described (Rattner et al. 2012a). The difference between the meatballs provided and scraps collected on a wet weight basis was defined as total food intake over the 7-day exposure period, and thus total CPN exposure.

Kestrels were observed three times daily during the toxicity trial, and were weighed and examined on days 0,3 and 5 of the exposure trial. On day 7, each bird was examined, weighed, bled, sacrificed using carbon dioxide, and then necropsied. Only 3 of 5 controls were sacrificed in the Classic Bird of Prey and in the RT control groups. Based on evidence of hemorrhage in our previous studies, portions of pectoral muscle, heart, liver, kidney and gastrointestinal tract were fixed in $10 \%$ phosphate-buffered formalin. The remaining portion of liver was frozen at $-80{ }^{\circ} \mathrm{C}$ for residue analysis. Microhematocrit was determined and the remainder of each blood sample was centrifuged, citrated plasma harvested, and various volumes pipetted into cryotubes that were stored frozen at $-80{ }^{\circ} \mathrm{C}$ for subsequent clotting time assays. 
Chlorophacinone purity and concentrations in diet and liver

The purity of neat CPN (CAS\# 3691-35-8) was determined by reversed phase ion-paired high-performance liquid chromatography (RP-HPLC) with UV detection at $285 \mathrm{~nm}$, using diphacinone as the internal standard, as previously described (Rattner et al. 2011, 2012a). The purity of CPN used in preparing mechanically-amended diets was found to be $99.6 \%$ (\% w/w).

Mechanically-amended and biologically-incorporated RT diets were homogenized, solvent extracted, purified using solid phase extraction cartridges, and CPN quantified by RP-HPLC (Rattner et al. 2012a). Recovery of CPN from spiked RT (mean $\pm \mathrm{SD}, \mathrm{n}=6$ ) was $82.9 \pm 12.37 \%$ at $0.198 \mu \mathrm{g} / \mathrm{g}$ and $89.4 \pm 4.90 \%$ at $1.95 \mu \mathrm{g} / \mathrm{g}$ wet weight. Chlorophacinone at nominal concentrations of $0.15,0.75$ and $1.5 \mu \mathrm{g} / \mathrm{g}$ wet weight in the mechanically-amended diets was quantified ( $\mathrm{n}=3 /$ level), and averaged $86.5 \pm$ $3.28,89.6 \pm 11.74$, and $92.4 \pm 9.67 \%$ of target concentrations. Chlorophacinone at nominal concentrations of $0.15,0.75$ and $1.5 \mu \mathrm{g} / \mathrm{g}$ wet weight in the biologicallyincorporated diets was quantified $(\mathrm{n}=3 /$ level) and averaged $98.2 \pm 7.82,100.1 \pm 3.59$, and $97.1 \pm 6.20 \%$ of target concentrations.

Liver samples of treated kestrels were analyzed for CPN as previously described in raptors (Rattner et al. 2011, 2012a). Recovery of CPN from spiked liver samples ( $\mathrm{n}=4 /$ level) averaged $71.3 \pm 13.76 \%$ at $0.46 \mu \mathrm{g} / \mathrm{g}$ and $91.9 \pm 6.45 \%$ at $4.30 \mu \mathrm{g} / \mathrm{g}$ wet weight. The method limit of detection and method limit of quantification for liver tissue was 0.049 and $0.16 \mu \mathrm{g} / \mathrm{g}$ wet weight, respectively.

\section{Clotting time assays}

Anticoagulant rodenticides inhibit vitamin $\mathrm{K}$ epoxide reductase that is required for the formation of vitamin $\mathrm{K}$ hydroquinone, the biologically active form of vitamin $\mathrm{K}$ required for $\gamma$-glutamyl carboxylation of clotting factors II, VII, IX and X (Rattner et al. 2014b). Prothrombin time (PT) and Russell's viper venom time (RVVT) of citrated plasma samples were used to examine CPN effects on posttranslational processing and activation of clotting factors. The conduct of these assays in citrated plasma from raptors has been described in detail (Rattner et al. 2011, 2012a, 2014a). The coefficient of variations (CVs) of duplicate determinations (mean \pm SD) of the baseline PT and RVVT samples were $5.6 \pm 4.30$ and $1.2 \pm 1.32 \%$, and for exposure trial PT and RVVT samples, the CVs were $4.5 \pm 5.56$ and $2.4 \pm 2.38 \%$. Thrombin clotting time (TCT) was used as an indicator of fibrinogen concentration in plasma. Fibrinogen deficiency resulting from improper sample collection can prolong clotting time, and in rodenticide toxicity studies it is important to verify that its concentration is adequate to promote clot formation (Rattner et al. 2010). Baseline fibrinogen concentration was $69.1 \pm 19.2 \mathrm{mg} / \mathrm{dL}$, with a $\mathrm{CV}$ of $1.6 \pm 1.49 \%$, and fibrinogen concentration for exposure trial samples was $85.6 \pm 42.9 \mathrm{mg} / \mathrm{dL}$, with a $\mathrm{CV}$ of $1.8 \pm 2.66 \%$.

\section{Histopathology}

Formalin-fixed tissues were processed and embedded in paraffin (American HistoLabs, Gaithersburg, MD) using standard procedures (Luna 1968). Tissues were sectioned at approximately $4 \mu \mathrm{m}$, mounted on slides, and stained with Carazzi's hematoxylin and eosin. Histologic evaluation was performed blind with no a priori determined criteria using the animal to animal technique with a subsequent re-evaluation. Severity was scored on a semiquantitative 0-4 scale (none, minimal, mild, moderate, severe, respectively).

\section{Statistical methods}

Measurement endpoints (body weight change, liver weight, liver to body weight ratio, food consumption, hematocrit, PT, RVVT, TCT, CPN consumption and liver residues) were tested for homogeneity of variance and normality (SAS version 9.3, SAS Institute, Carey, NC). Liver samples with CPN residue levels that were $\angle$ MLOD ( $n=3$ of 30 ) were assigned a value of one-half the MLOD (USEPA 2000). Measurement endpoints (excluding CPN consumption and liver residues) were first compared between control groups (i.e., Classic Bird of Prey diet and RT diet) using Student's $t$ tests, and because they did not differ ( $p=0.16-0.98)$, they were combined into a single control group. Subsequently, measurement endpoints were compared among all groups by one-way analysis of variance (mixed model) and Tukey's HSD test. Body weight change (days 3, 5 and 7) relative to initial day 0 weight (weight change/100 g body weight) was evaluated over time using a repeated measures analysis of variance. A suspect control RVVT value, exceeding pre-study and control values by more than 5 standard deviations, was confirmed as an outlier using Grubb's test and excluded from the data set (Motulsky 2010). Liver CPN concentrations of the 6 treatment groups were tested using the aforementioned parametric methods and simple linear regression, assigning a value of one-half the MLOD to 3 of 30 samples for which CPN was not detected.

The quantity of ingested CPN and the concentration of CPN in liver of kestrels with prolonged clotting time were used to derive dietary-based and tissue-based toxicity reference values (Filipsson et al. 2003; USEPA 2011b). Response parameters included estimated CPN consumption/ 
kg body weight-day (arithmetic mean of each group) and CPN residue in liver (geometric mean of each group) compared to clotting time (dichotomous: number of kestrels in each treatment group exceeding mean baseline clotting time by $>2$ standard deviations). Using this dose-response curve, benchmark doses at the 10,50 and $90 \%$ effect levels (BMD10, BMD50 and BMD90) and benchmark dose lows (BMDL, lower bound of the $95 \% \mathrm{CI}$ at these response levels) were calculated using gamma, multi-stage, Weibull, quantal-linear, logistic, log-logistic, probit and log-probit models. Akaike's Information Criterion and $p$ values were used to select the most appropriate model for these data.

\section{Results}

Chlorophacinone exposure and toxicity

Daily food consumption, expressed on a dry weight or wet weight basis as grams consumed per kilogram kestrel, did not differ among groups (Table 1). Daily food consumption and measured quantities of CPN in diets were used to estimate exposure. Chlorophacinone consumed by the 6 treatment groups ranged from 30.7 to $354.1 \mu \mathrm{g} / \mathrm{kg}$ body weight-day (Table 1) and the estimated 7-day cumulative dose ranged from 215 to $2,478 \mu \mathrm{g} / \mathrm{kg}$ body weight. Statistically significant differences $(p<0.05)$ in exposure were apparent among dose levels, but were comparable for both the mechanically-amended and biologically-incorporated diets (Table 1). Chlorophacinone was detected in liver of 3 of 5 kestrels fed the mechanically-amended $0.15 \mu \mathrm{g} / \mathrm{g}$ diet, 4 of 5 individuals receiving the biologically-incorporated $0.15 \mu \mathrm{g} / \mathrm{g}$ diet, and present in all birds fed diets containing 0.75 or $1.5 \mu \mathrm{g} / \mathrm{g}$ (Table 1). While residues seemed to be greater in both the 0.75 or $1.5 \mu \mathrm{g} / \mathrm{g}$ groups compared to the lower dietary dose groups, a difference in residue concentrations was only significant $(p<0.05)$ compared to kestrels fed the biologicallyincorporated $1.5 \mu \mathrm{g} / \mathrm{g}$ diet. However, a simple linear regression revealed that the cumulative dietary dose per bird was associated with $\mu \mathrm{g}$ CPN per $\mathrm{g}$ liver after the 7-day exposure period $\left(p<0.001\right.$, adjusted $\mathrm{R}^{2}=0.31, \mathrm{n}=30$ ) (Supplement S1).

All kestrels survived the 7-day feeding trial, and very few exhibited overt signs of intoxication or macroscopic evidence of hemorrhage at necropsy. A kestrel receiving mechanically-amended CPN at a dose of $0.15 \mu \mathrm{g} / \mathrm{g}$ diet appeared poorly preened between days 3 and 7 and its liver appeared pale at necropsy. In the mechanically-amended $1.5 \mu \mathrm{g} / \mathrm{g}$ group, one kestrel exhibited some frank blood on its feathers when captured on day 7 , and two others appeared to have pale viscera at necropsy. In the biologically-incorporated $1.5 \mu \mathrm{g} / \mathrm{g}$ group, one kestrel was

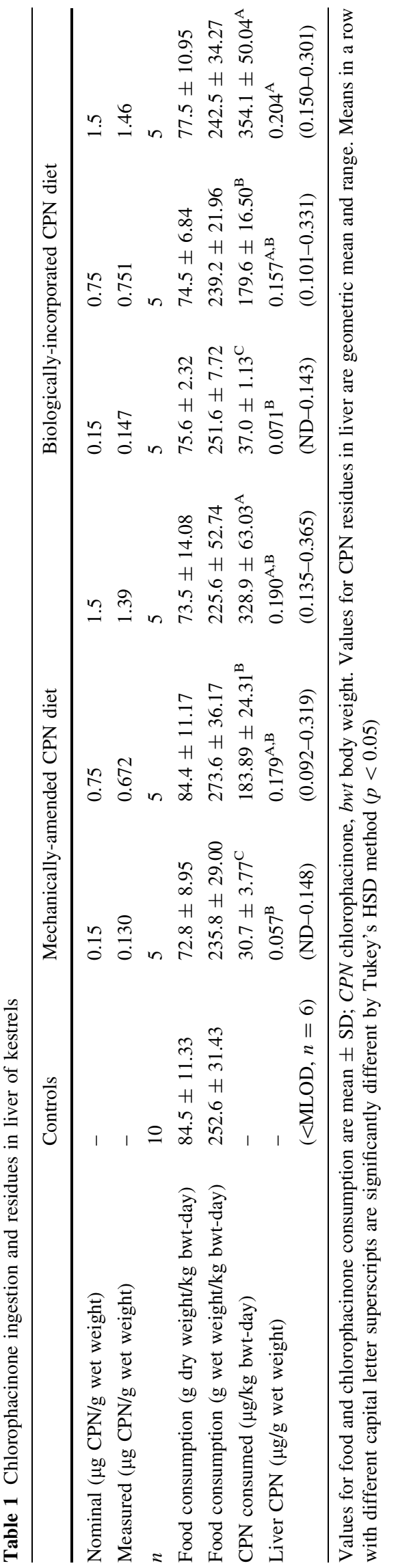


bleeding from its nares on day 7 , and had pale viscera and a swollen liver at necropsy, and another kestrel had a bruise on the featherless tract of its neck (Fig. 1, compare a and b). The repeated measures ANOVA detected a treatment effect on body weight change $(p<0.05)$, however, average body weight change fluctuated by $<6 \%$ and did not vary in a dose-dependent manner. On average, kestrels receiving biologically-incorporated $\mathrm{CPN}$ at $1.5 \mu \mathrm{g} / \mathrm{g}$ diet gained the most weight. For illustrative purposes, body weight change after the 7-day exposure period $(\Delta \mathrm{g} / 100 \mathrm{~g}$ initial body weight) is presented in Table 2 . Liver weight (range of means: $2.01-2.37 \mathrm{~g}$ ) and liver to body weight ratio (range of means: $1.90-2.18 \mathrm{~g} / 100 \mathrm{~g}$ body weight) did not differ among groups $(p>0.15)$.

Microscopic evidence of mild to moderate hemorrhage was apparent in various tissues of kestrels fed either
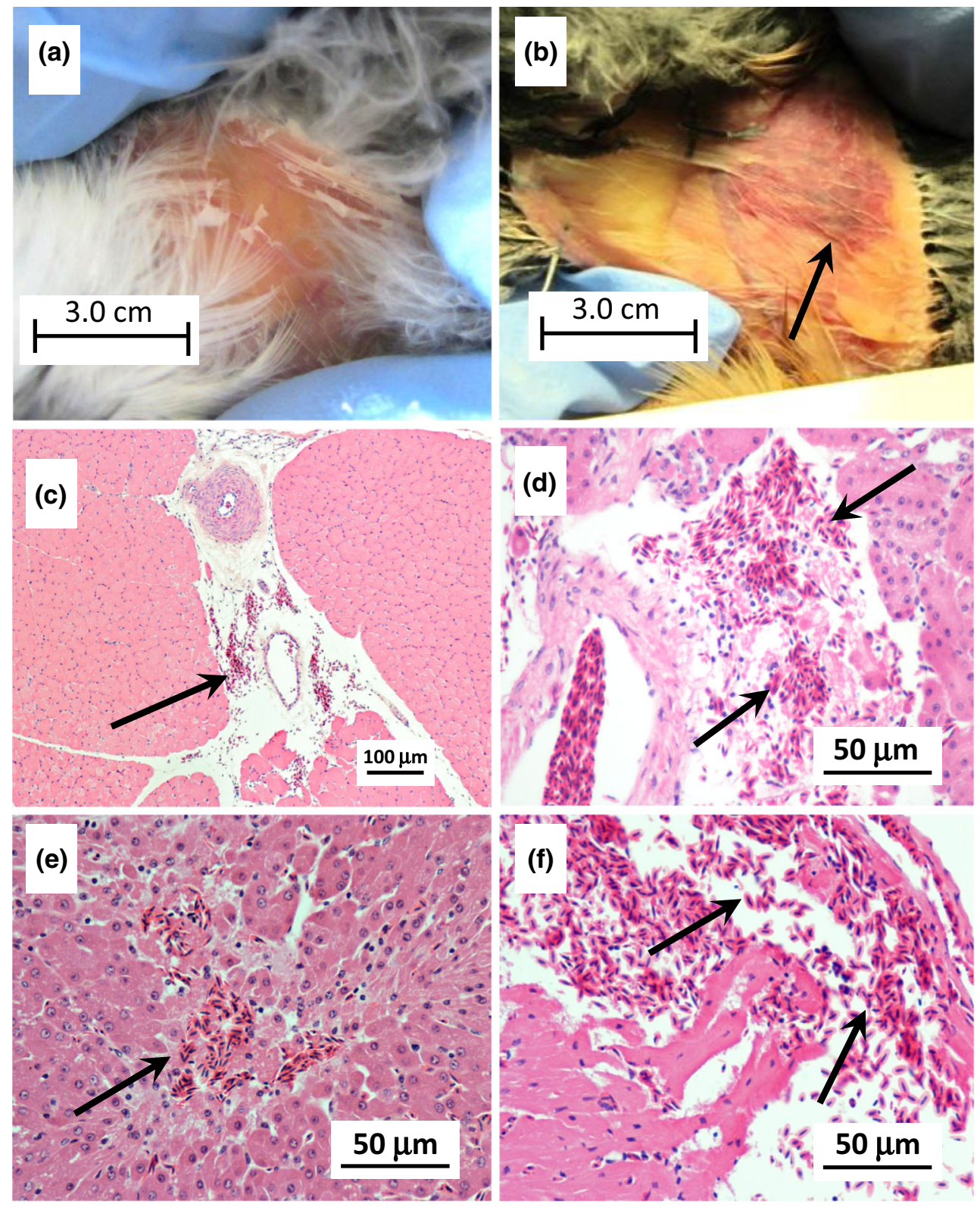

Fig. 1 a Featherless tract along neck of control America kestrel; b bruising of featherless tract of a kestrel fed rat tissue containing biologically-incorporated $\mathrm{CPN}$ at $1.5 \mu \mathrm{g} / \mathrm{g}$ wet weight diet; c moderate perivascular hemorrhage in pectoral muscle of kestrel fed rat tissue mechanically-amended with $\mathrm{CPN}$ at $0.15 \mu \mathrm{g} / \mathrm{g}$; d tubular disruption and multifocal hemorrhage in kidney of kestrel fed rat tissue

mechanically-amended with $\mathrm{CPN}$ at $0.75 \mu \mathrm{g} / \mathrm{g}$; e mild hemorrhage in liver of kestrel fed rat tissue containing biologically-incorporated $\mathrm{CPN}$ at $1.5 \mu \mathrm{g} / \mathrm{g} ; \mathbf{f}$ focally extensive area of left ventricular subepicardial hemorrhage of kestrel fed rat tissue mechanicallyamended with CPN at $1.5 \mu \mathrm{g} / \mathrm{g}$ 


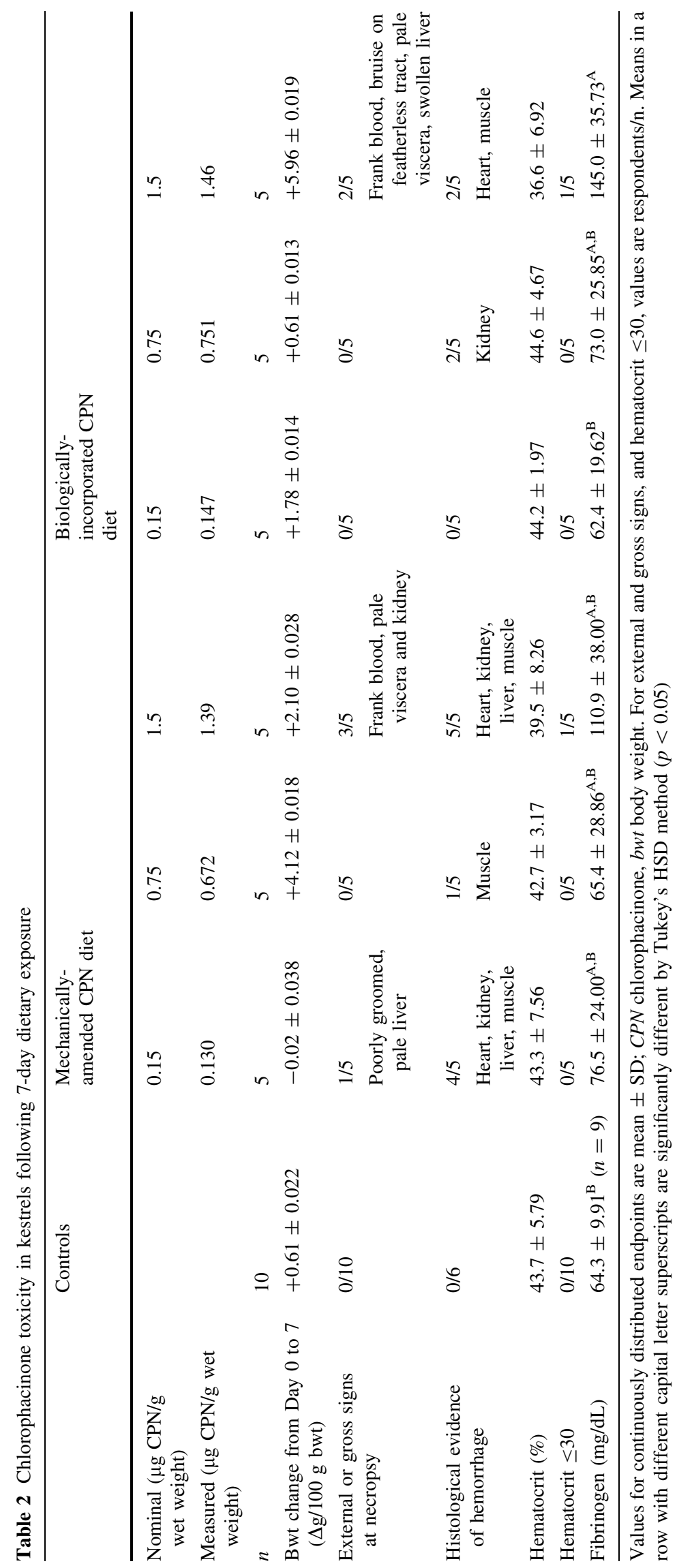


mechanically-amended or biologically-incorporated CPN diets, but not in controls (Table 2; Fig. 1c-f). Prevalence did not appear to be dose-related, although this might be a function of examining only a few sections in a portion of each tissue. Incidental findings, with no evidence of clinical disease, included mild inflammation in the pectoral muscle, kidney, liver and heart, mild necrosis in the kidney and heart, lymphoid aggregates in the kidney and liver, vacuolation in tunica media and adventitia of arteries in the pectoral muscle, kidney, heart, and intestine, and the presence of sarcocysts in pectoral muscle and heart of onethird of the birds. In addition, there were several organ specific changes including mild degeneration and regeneration of pectoral muscle, sloughed cells in tubular lumina of the kidney, scattered mineralization in the kidney, eosinophilic lace-like fibers or clear variably-sized round vacuoles (glycogen, lipid) in the cytoplasm of hepatocytes, pigmented macrophage aggregates in the liver, Kupffer cells with golden brown to orange intracytoplasmic pigment, thickening of the tunica media of portal arteries in the liver, and mineralization of valves and blood vessels in the heart.

Although hematocrit appeared to be slightly depressed in kestrels fed CPN at $1.5 \mu \mathrm{g} / \mathrm{g}$ (Table 2), there were no statistically significant differences among groups $(p>0.25)$. However, inspection of these data revealed that 1 of 5 individuals in the mechanically-amended $1.5 \mu \mathrm{g} / \mathrm{g}$ group had a hematocrit of $<30$, and was thus classified as anemic (Goodwin et al. 1992). Likewise, in the biologically-incorporated $1.5 \mu \mathrm{g} / \mathrm{g}$ group, 1 of 5 individuals was anemic, and two other kestrels were close to being categorized as anemic.

Baseline PT and RVVT values (mean $\pm \mathrm{SD}$ ) were $12.02 \pm 2.03$ seconds (s) and $18.13 \pm 2.42 \mathrm{~s}$, respectively. Both PT and RVVT of kestrels fed 0.75 and $1.5 \mu \mathrm{g} /$ g CPN diets for 7 days were prolonged $(p<0.05)$ as much as sevenfold when compared to clotting times of the $0.15 \mu \mathrm{g} / \mathrm{g}$ and control groups (Fig. 2). Notably, RVVT for 1 of 5 kestrels in the mechanically-amended $0.15 \mu \mathrm{g} / \mathrm{g}$ group, and 2 of 5 kestrels in the biologically-incorporated $0.15 \mu \mathrm{g} / \mathrm{g}$ group, exceeded the mean baseline clotting time value by more than two standard deviations. Mechanicallyamended and biologically-incorporated diet formulations had similar effects on clotting time. Fibrinogen concentration (insensitive to direct effects of ARs on vitamin $\mathrm{K}$ epoxide reductase) exceeded the mean baseline value $(69.1 \pm 19.2 \mathrm{mg} / \mathrm{dL})$ by $>2$ standard deviations in 3 of 5 kestrels in both mechanically-amended and biologicallyincorporated $1.5 \mu \mathrm{g} / \mathrm{g}$ groups. However, this apparent difference in fibrinogen concentration was only statistically significant $(p<0.05)$ between the biologically-incorporated $1.5 \mu \mathrm{g} / \mathrm{g}$ group and controls at the end of the feeding trial (Table 2).
Dietary- and tissue-based toxicity reference values

Using daily CPN consumption and the fraction of birds in each group with clotting time exceeding baseline by 2 standard deviations yielded estimates of dietary-based toxicity reference values. The dose-response curve for PT was very steep (best fit: log-logistic model), such that PT was not affected at the low CPN dietary dose, while all kestrels exceeded baseline values at both the intermediate and high CPN doses. The BMD10, BMD50 and BMD90, and corresponding parenthetical BMDLs, for PT were estimated to be 70.1 (32.5), 79.2 (39.6) and 89.4 (44.7) $\mu \mathrm{g}$ CPN consumed/kg body weight-day, respectively (Fig. 3a). The dose-response curve for RVVT was also steep (best fit: logistic model), but several kestrels in the $0.15 \mu \mathrm{g} / \mathrm{g}$ groups exceeded baseline clotting time values. The BMD10, BMD50 and BMD90, and BMDLs for RVVT were estimated to be 26.4 (12.6), 39.1 (32.6) and 51.9 (39.5) $\mu \mathrm{g} \mathrm{CPN}$ consumed/kg body weight-day, respectively (Fig. 3b).

Tissue-based toxicity reference values were estimated using the geometric mean CPN concentration in liver for each group and the fraction of birds with clotting time exceeding the baseline mean by 2 standard deviations. The dose-response curve for PT was steep (best fit: $\log$ probit model). Prothrombin time was not affected at the low CPN residue concentrations, while nearly all birds exceeded baseline PT values at the intermediate and high liver residue concentrations. The BMD10, BMD50 and BMD90 and corresponding BMDLs for PT were estimated to be 0.099 (0.064), 0.107 (0.074) and $0.114(0.079) \mu \mathrm{g} \mathrm{CPN} / \mathrm{g}$ liver wet weight, respectively (Fig. 4a). The doseresponse curve for RVVT was also steep (best fit: probit model), with several kestrels in the $0.15 \mu \mathrm{g} / \mathrm{g}$ groups exceeding baseline clotting time values. The BMD10, BMD50 and BMD90, and corresponding BMDLs, for RVVT were estimated to be 0.048 (0.021), $0.076(0.061)$ and 0.105 (0.076) $\mu \mathrm{g}$ CPN/g liver wet weight, respectively (Fig. 4b).

\section{Discussion}

Chlorophacinone evoked overt signs of intoxication and histopathological lesions, and impaired blood clotting in American kestrels-effects that are consistent with the mechanism of action of ARs (Rattner et al. 2014b). In contrast to previous CPN toxicity studies in raptors (Mendenhall and Pank 1980; Radvanyi et al. 1988; Riedel et al. 1988; Askham and Poché 1992), both the concentration of CPN in food and the quantity of food consumed by birds were measured to estimate the daily dose. Using data from the present study, a $100 \mathrm{~g}$ adult kestrel ingested 
Fig. 2 a Prothrombin time and b Russell's viper venom time of American kestrels fed control diet (Classic Bird of Prey $=$ X, Rat tissue $=\bullet$ ), or mechanically-amended or biologically-incorporated CPN diets for 7 days (individual values in seconds and mean $\pm \mathrm{SD})$. Horizontal shaded area is the range of baseline values determined 2 weeks before the trial. Bars with different letters are significantly different $(p<0.05)$ (a)

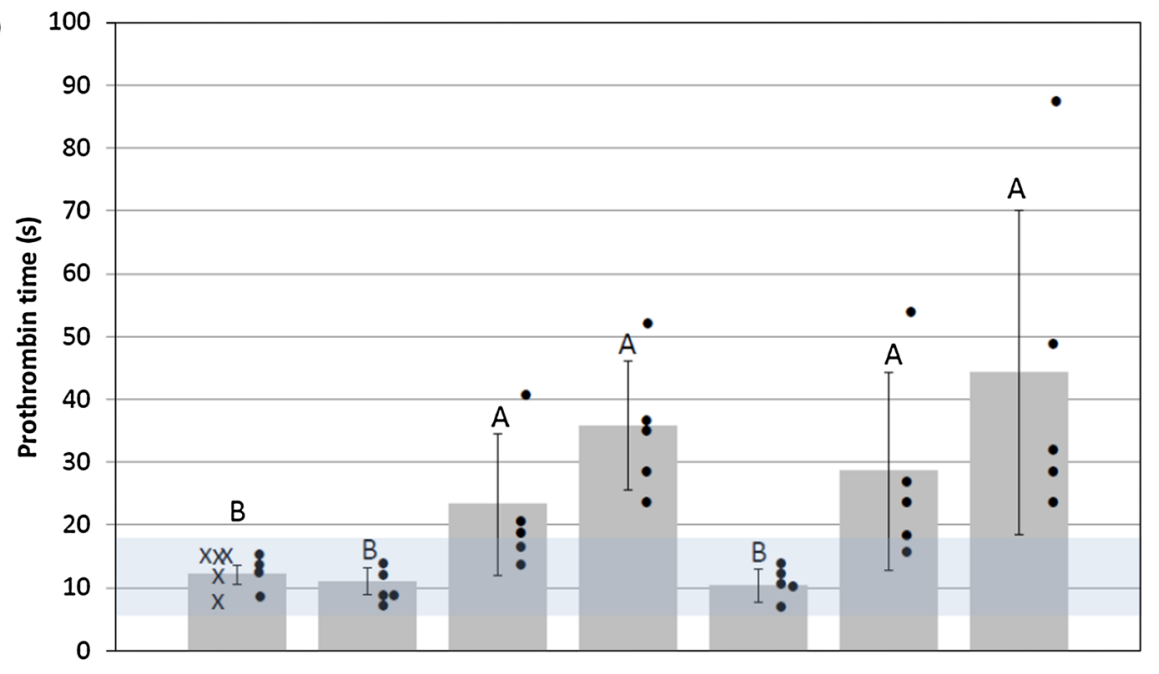

(b)

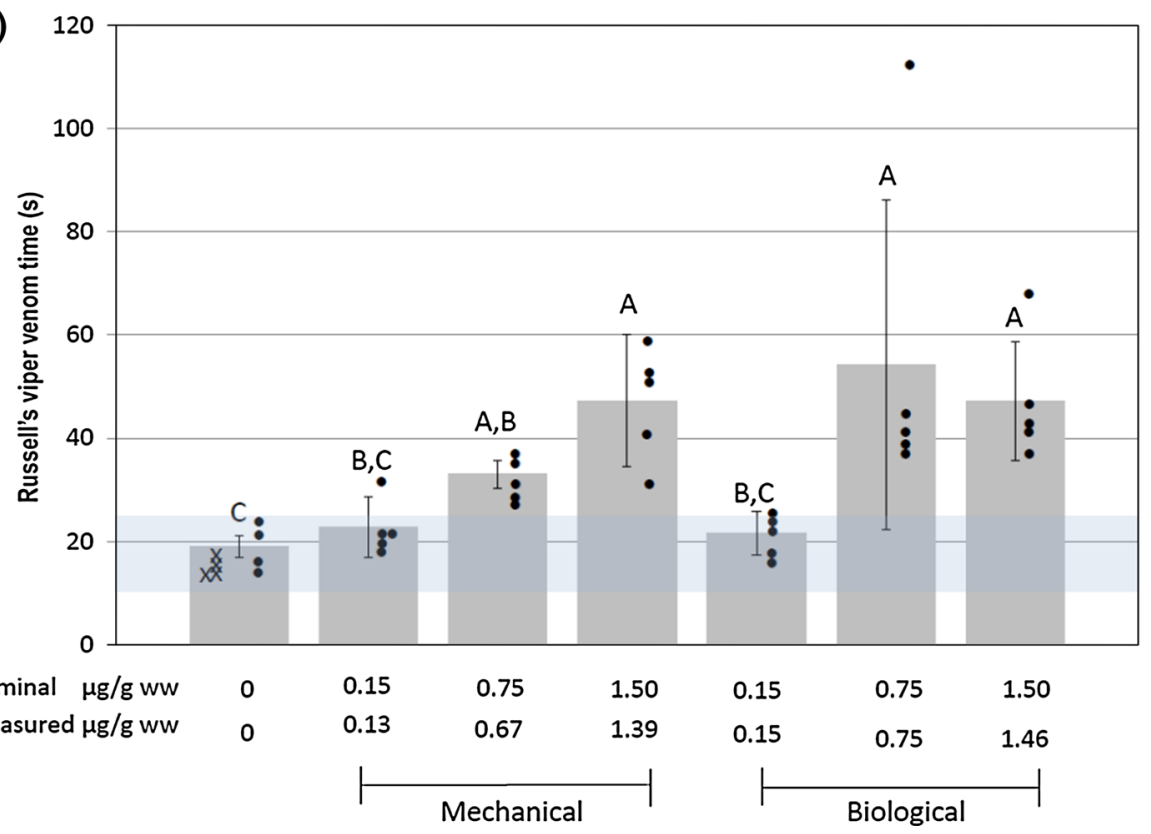

on average $7.84 \mathrm{~g}$ of food on a dry weight basis per day (Table 1, average across groups), which falls in the range of values (5.51-7.99 $\mathrm{g}$ dry weight per day) reported or estimated (converting wet to dry weight using $67.8 \%$ average moisture content of food from the present study) for captive kestrels (body weight: 91-113 g) fed lean beef, venison or mice (Wing and Wing 1939; Craighead and Craighead 1956; Duke et al. 1976). It is noteworthy that these values are considerably lower than the bioenergetic estimate (Nagy 1987) of $13 \mathrm{~g}$ dry weight per day for a 100 gram free-ranging kestrel that must forage naturally.

Food consumption of kestrels did not differ among control and treatment groups, and thus, exposure was proportional to CPN concentration in the diet. Because dietary CPN levels were a function of carcass residues of rats fed Rozol ${ }^{\circledR}$ bait for 3 days, it is believed that the concentrations (range: $0.13-1.46 \mu \mathrm{g} / \mathrm{g}$ wet weight food) are environmentally realistic. This is substantiated by observations in Belding's ground squirrels (Spermophilus beldingi), pocket gophers (Thomomys bottae) and voles (Microtus spp.) following field baiting trials; mean carcass CPN residues (liver, head, pelt and appendages removed) ranged from 0.131 to $1.59 \mu \mathrm{g} / \mathrm{g}$ wet weight (Primus et al. 2001; Ramey et al. 2007), which not only overlaps, but exceeds dietary concentrations employed in the present study.

\section{Signs of toxicity}

Short-term dietary CPN exposure of kestrels resulted in external evidence of bleeding, bruising, anemia, or pale viscera in half of the birds receiving a nominal concentration of $1.5 \mu \mathrm{g} / \mathrm{g}$ diet, with microscopic evidence of 
Fig. 3 Dose-response relation of CPN consumed and clotting time of American kestrels (adapted in part from Rattner et al. 2014c). a Using the benchmark dose method, dietary-based toxicity reference values at which prothrombin time exceeded 10, 50 and $90 \%$ of the test population by 2 standard deviations above baseline mean (BMD10, BMD50, BMD90) occurred at 70.1, 79.2 and $89.4 \mu \mathrm{g} \mathrm{CPN}$ consumed/kg body weight-day. b Dietary-based toxicity reference values at which Russell's viper venom time exceeded 10, 50 and $90 \%$ of the test population by 2 standard deviations above baseline mean occurred at 26.4, 39.1 and $51.9 \mu \mathrm{g}$ CPN consumed/kg body weight-day

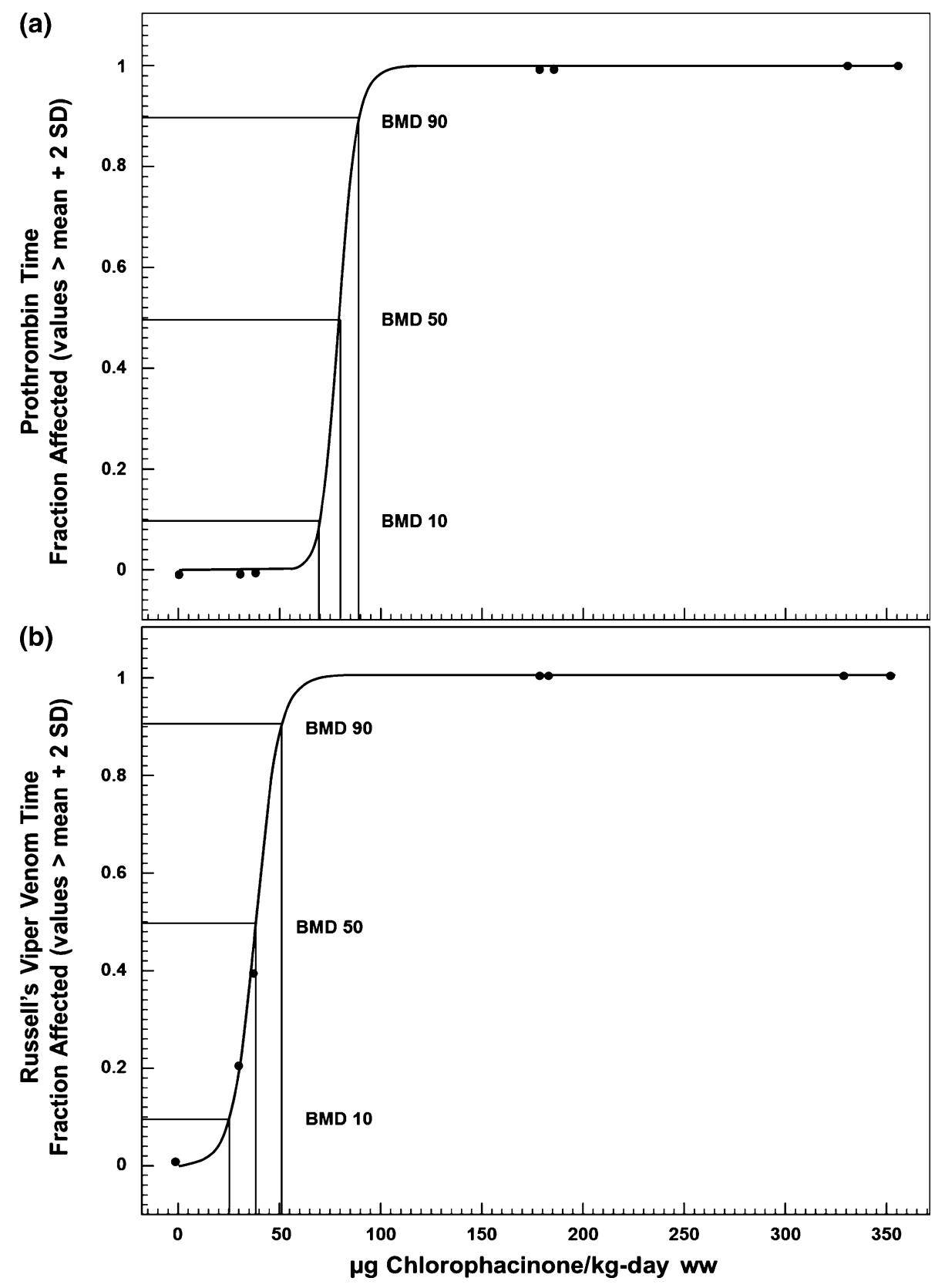

hemorrhage apparent at even lower levels of exposure. Accordingly, there may be toxicity (prolonged clotting time, histological lesions) without overt signs of intoxication. These responses are the direct consequence of inhibition of vitamin $\mathrm{K}$ epoxide reductase, and failure to form active clotting factors necessary for hemostasis (Rattner et al. 2014b). Using PT and RVVT as biomarkers, prolonged clotting time was readily apparent in kestrels receiving CPN at doses of 0.75 and $1.5 \mu \mathrm{g} / \mathrm{g}$ diet. These responses were quite similar to those observed in Eastern screech-owls (Megascops asio) fed the closely-related FGAR diphacinone at a slightly greater concentration (2.15 $\mu \mathrm{g}$ CPN/g diet for 7 days) (Rattner et al. 2012a).
Notably, there was some evidence that fibrinogen concentration actually increased in kestrels receiving CPN at $1.5 \mu \mathrm{g} / \mathrm{g}$ diet. Similar findings (i.e., up-regulation of fibrinogen) have been described in rats fed the SGAR difenacoum, and was attributed to changes in factor $\mathrm{X}$ and other vitamin K-dependent clotting factors through a feedback mechanism (Kerins 1999).

The present study compared toxicological responses of kestrels receiving mechanically-amended or biologicallyincorporated dietary formulations of CPN. Recently, three hydroxylated CPN metabolites (two sites on a side chain, one on an indandione phenyl ring) have been isolated in liver tissue of AR-resistant and -susceptible rats in a 
Fig. 4 Dose-response relation of hepatic CPN concentration and clotting time of American kestrels. a Using the benchmark dose method, tissue-based toxicity reference values at which prothrombin time exceeded 10, 50 and $90 \%$ of the test population by 2 standard deviations above baseline mean (BMD10, BMD50, BMD90) occurred at $0.099,0.106$ and $0.114 \mu \mathrm{g} / \mathrm{g}$ liver wet weight. b Tissue-based toxicity reference values at which RVVT in 10,50 and $90 \%$ of the test population exceeded the baseline mean by 2 standard deviations occurred at 0.048 , 0.076 and $0.105 \mu \mathrm{g} / \mathrm{g}$ liver wet weight
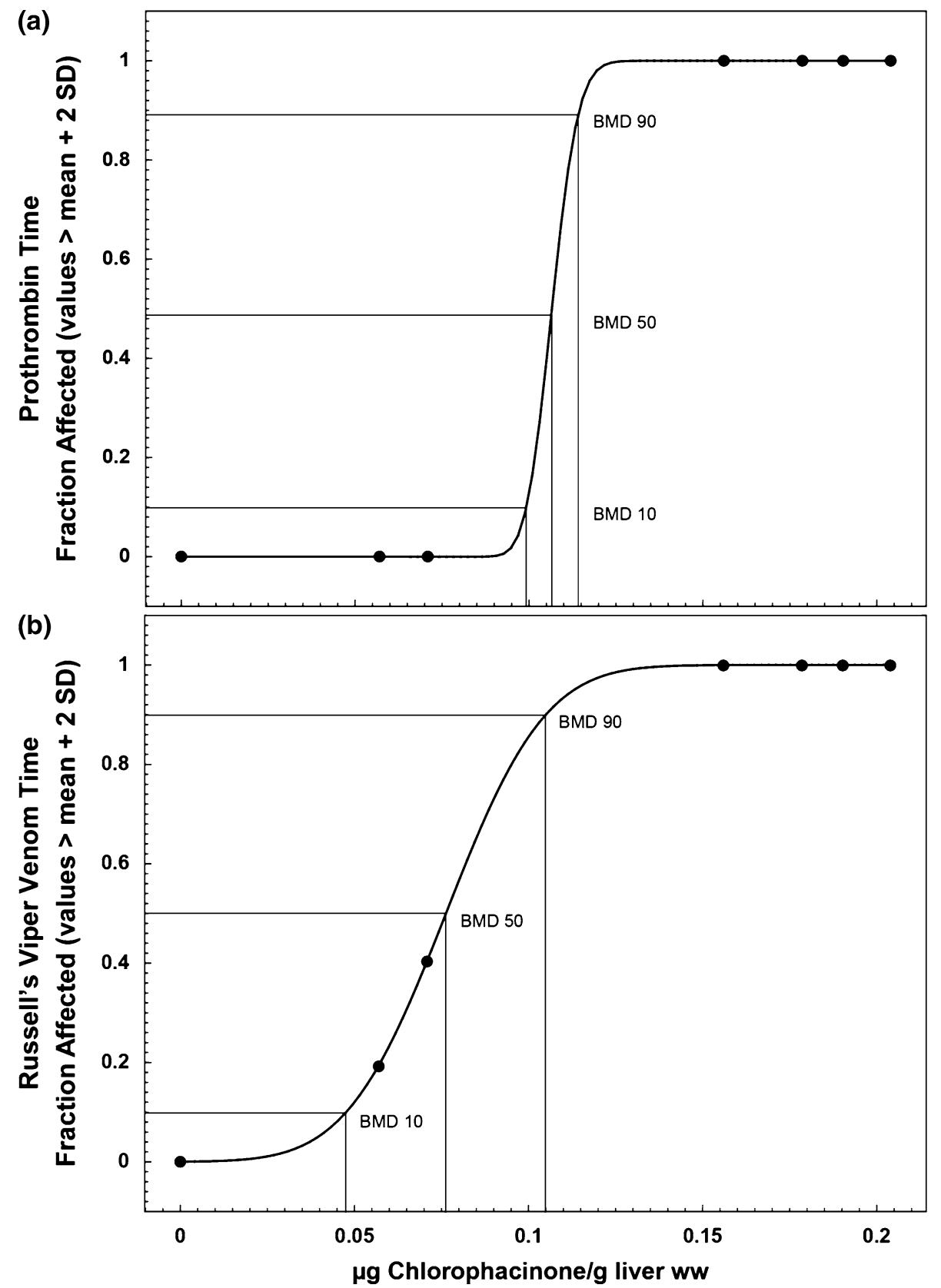

bioaccumulation study (Vein et al. 2013). It was suggested that the side chain hydroxylated metabolites may even retain some anticoagulant activity (Vein et al. 2013), which incidentally, does not seem to be the case for hydroxylated metabolites of the FGAR warfarin (Sutcliffe et al. 1987). While not quantified in the biologically-incorporated CPN diet, it is likely that the diet contained both CPN and hydroxylated metabolites. However, there was no evidence of a differential effect of dietary CPN formulation on overt signs of intoxication, hematocrit or clotting time.

Although kestrels exhibited typical signs of AR toxicity (e.g., bruising, frank bleeding, blood in droppings, pallor; see Stone et al. 1999, Murray 2011, Rattner et al. 2014b), none succumbed during the 7-day feeding trial. Notably, kestrels have been fed CPN-poisoned mice for 21 days, and while there was evidence of behavioral effects, and hemorrhage at necropsy, none died during the trial (Radvanyi et al. 1988). In other studies in which CPNpoisoned rodents were fed to barn owls, a great horned owl, Eurasian buzzards (Buteo buteo) and red-tailed hawks (Buteo jamaicensis) for 7-10 days, no mortality was observed (Mendenhall and Pank 1980; Riedel et al. 1988; Askham and Poché 1992). Such tolerance observed in captive birds may not be the case for free-ranging raptors, 
as documented in several mortality incident reports (Berny et al. 1997; CAEPA 2013; USEPA 2011a, 2012; USFWS 2012). Our own studies suggest that raptors may recover in a matter of days to weeks following withdrawal of exposure to the closely-related FGAR diphacinone (Savarie et al. 1979, Rattner et al. 2014a), although exposure to SGARs may result in long lasting inhibition of vitamin $\mathrm{K}$ epoxide reductase, potentially rendering animals highly susceptible to subsequent AR exposure (Mosterd and Thijssen 1991). It has been suggested that AR toxicity may be affected by body condition, and exacerbated by other environmental stressors (e.g., extreme weather, foraging energetics), nutrition (e.g., vitamin $\mathrm{K}$ status, nutritional quality of synthetic laboratory diets versus natural food), disease, other contaminants (lead-induced anemia), and blood loss during molt (Rattner et al. 2014b).

\section{Chlorophacinone residues in liver}

Following the 7-day exposure period, CPN residues in liver tended to be related to dietary dose. There were no differences in residue concentrations between corresponding doses of the mechanically-amended and biologicallyincorporated diets, suggesting relatively similar CPN bioavailability and accumulation for the two formulations. The maximum CPN residue found in liver was less than $0.005 \%$ of the ingested dose. Elimination rate of CPN has yet to be studied in birds. In laboratory mice, the elimination of the indandione CPN is biphasic, with overall halflife estimates of 35.4 days for liver and 11.7 days for blood plasma, which is less than that of several coumarin-based first- and second-generations ARs (Vandenbroucke et al. 2008). The comparatively short half-life of CPN may account for its low detection frequency (Berny et al. 1997; Stone et al. 1999, 2003; Albert et al. 2010; Murray 2011; Hughes et al. 2013; Vyas et al. 2013) and low hepatic concentrations in predatory bird mortality incidents (i.e., $0.18-0.40 \mu \mathrm{g} / \mathrm{g}$ liver wet weight in barn owl, great horned owl, red-tailed hawk, ferruginous hawk, and bald eagles, with the exception of one eagle, Aquila sp. with $6.2 \mu \mathrm{g} / \mathrm{g}$ liver; Berny et al. 1997; USEPA 2011a, 2012; USFWS 2012). Tissue concentrations of SGARs associated with mortality of predatory birds have been suggested to be in the range of $0.1-0.2 \mu \mathrm{g} / \mathrm{g}$ liver (Newton et al. 1999), and perhaps even $<0.1 \mu \mathrm{g} / \mathrm{g}$ (Thomas et al. 2011). Such diagnostic thresholds for mortality have yet to be established for FGARs. Perhaps one complicating issue in diagnosis of FGAR intoxication is that much of the residue might be cleared before the exposed animal succumbs. Definitive diagnoses of secondary poisoning in raptors attributable to FGARs is quite low, and some investigators explicitly state that FGAR-related mortality in non-target wildlife is less likely to occur than with SGARs (e.g., Berny et al. 1997;
Stone et al. 2003; Shlosberg and Booth 2006; USEPA 2011a).

Risk assessment and application of toxicity reference values

The hazard of CPN to non-target wildlife has recently been evaluated using deterministic risk assessment methods that depend heavily on the use of risk quotients. Based on single-day acute oral and short-term dietary exposure studies with Northern bobwhite, CPN is moderately to highly toxic, but predicted to pose limited risk to non-target birds consuming poisoned-prey (USEPA 2011a). However, data from single-day acute oral toxicity studies are not appropriate for evaluation of FGARs that require multiple feedings to evoke toxicity (Vyas and Rattner 2012). Nonetheless, both single-day acute oral and multi-day short-term dietary exposure studies with captive kestrels and Eastern screech-owls have demonstrated that raptors are considerably more sensitive to the FGAR diphacinone than traditional avian test species such as Northern bobwhite (Rattner 2011, 2012a, b). It is noteworthy that a deterministic risk assessment predicted that CPN could pose a significant hazard to birds directly consuming bait (USEPA 2011a), and such effects have been documented in California quail (Callipepla californica) and wild turkeys (Meleagris gallopavo) (USEPA 2011a), and recently in a western meadowlark (Sturnella neglecta) (Vyas et al. 2013).

In the present study, a range of daily dietary doses and the fraction of individuals exhibiting prolonged clotting times were used to generate dietary-based toxicity reference values. It was estimated that half of the individuals would exhibit prolonged PT at a daily dose of $79.2 \mu \mathrm{g} / \mathrm{kg}$ body weight and prolonged RVVT at a daily dose of $39.1 \mu \mathrm{g} / \mathrm{kg}$ body weight, which is in agreement with values in a preliminary report (Rattner et al. 2014c). Using a $100 \mathrm{~g}$ kestrel as a model for raptors (Bardo and Bird 2009), these PT and RVVT effect thresholds would correspond to consumption of about 7.9 and $3.9 \mu \mathrm{g} / \mathrm{bird}$-day, respectively. As described above, mean carcass concentrations of CPN reported for 3 species of small mammals following field baiting trials ranged from 0.131 to $1.59 \mu \mathrm{g} / \mathrm{g}$ wet weight (Primus et al. 2001; Ramey et al. 2007). Applying the average moisture content estimate (i.e., $67.8 \%$ ) and the derived wet to dry weight conversion factor (i.e., 3.10) from the present study, these small mammal carcass CPN values would correspond to approximately $0.406-4.93 \mu \mathrm{g} /$ $\mathrm{g}$ on a dry weight basis. Based upon daily food consumption for captive kestrels $(\sim 6.92 \mathrm{~g}$ dry weight, average from Wing and Wing 1939; Craighead and Craighead 1956; Duke et al. 1976; and present study), the quantity of CPN ingested by birds feeding exclusively on poisoned 
prey would range from 2.81 to $34.1 \mu \mathrm{g} / \mathrm{day}$, which encompasses the thresholds associated with coagulopathy (7.9 and 3.9 $\mu \mathrm{g}$ CPN/bird-day for PT and RVVT) in $50 \%$ of exposed individuals. Using food consumption estimates for a free-ranging kestrel (13 g dry weight per day; $\sim 1.65$ times greater than consumption for captive kestrels in the present study), the quantity of CPN ingested daily by birds feeding exclusively on poisoned prey would range from 5.28 to $64.1 \mu \mathrm{g} / \mathrm{day}$, and the risk of coagulopathy might be greater. While prey availability, daily consumption, CPN residues and even unabsorbed AR-containing bait in the gut of target species are likely to vary considerably, these data suggest that ingestion of CPN-exposed prey by raptors for an extended period (e.g., 1-week or longer) could result in coagulopathy.

Our findings demonstrate that short-term dietary exposure to CPN resulting in liver residue concentrations of approximately $0.107 \mu \mathrm{g} / \mathrm{g}$ wet weight was associated with prolonged PT in $50 \%$ of the exposed kestrels. Even lower CPN residue levels $(0.076 \mu \mathrm{g} / \mathrm{g})$ resulted in prolonged RVVT in half of the exposed kestrels. These tissue-based toxicity reference values for coagulopathy are below liver CPN concentrations reported in raptor mortality incidents (0.18-6.2 $\mu \mathrm{g}$ CPN/g liver; Berny et al. 1997; USEPA 2010, 2011a; USFWS 2012). Furthermore, hepatic CPN concentrations are lower than reported for the FGAR diphacinone in Eastern screech-owls (i.e., BMD50 for PT $=0.345 \mu \mathrm{g} / \mathrm{g}$ liver wet weight; BMD50 for $\mathrm{RVVT}=0.319 \mu \mathrm{g} / \mathrm{g}$ liver) (Rattner et al. 2014a), which is consistent with the comparatively greater toxicity of CPN in short-term dietary studies in Northern bobwhite and mallards (USEPA 2011a). These toxicity reference values for coagulopathy fall in the range of concentrations reported for dead raptors (i.e., $0.1-0.4 \mu \mathrm{g} / \mathrm{g}$ liver) exhibiting signs of hemorrhage (Newton et al. 1999; Stone et al. 1999, 2003; Albert et al. 2010). While coagulopathy is a key event in the adverse outcome pathway of ARs (Rattner et al. 2014b), fatal hemorrhage in AR exposed animals seems to be a multi-causal phenomenon (Kaukeinin 1982), and predicting overall consequences is quite challenging (Rattner et al. 2014b).

\section{Conclusions}

Dietary exposure to environmentally realistic levels of CPN evoke signs of toxicity in captive American kestrels that are consistent with the cellular, organ, and whole animal responses described in the adverse outcome pathway for ARs in raptors (Rattner et al. 2014b). Registration data, peer-reviewed published literature, and risk assessments suggest that the FGAR CPN is less hazardous than SGARs. However, a direct comparison of the toxicity of various FGARs and SGARs using environmentally relevant exposure scenarios has yet to be adequately evaluated. The effects of intermittent FGAR exposure, and sequential combinations of FGARs and SGARs on raptors are unclear, and warrant investigation. The hazards of CPN and the FGAR diphacinone (Rattner et al. 2011, 2012a, b, 2014a) to non-target predatory birds may be greater than previously perceived, and needs to be considered in weighing the costs and benefits of AR use in pest control and eradication programs.

Acknowledgments The authors acknowledge W.C. Bauer, D.A. Goldade, J. Green, P.F.P. Henry, C.S. Hulse, N.K. Karouna-Renier, M.M. Maxey, and D.T. Sprague for assistance with the conduct of this study, and thank N.B. Vyas for reviewing a draft of this manuscript. A preliminary report describing dietary-based toxicity reference values for chlorophacinone was presented at the 26th Vertebrate Pest Conference and is described in the proceedings of that meeting. This work was supported by the U.S. Department of Agriculture, U.S. Geological Survey and a grant from the California Department of Food and Agriculture Vertebrate Pest Control Research Advisory Committee (agreement 11-0430-SA). Any use of trade, product or firm names is for descriptive purposes only and does not imply endorsement by the U.S. Government.

Conflict of interest The authors declare that they have no conflict of interest.

\section{References}

Albert CA, Wilson LK, Mineau P, Trudeau S, Elliott JE (2010) Anticoagulant rodenticides in three owl species from western Canada, 1988-2003. Arch Environ Contam Toxicol 58:451-459

Askham LR, Poché RM (1992) Biodeterioration of chlorophacinone in voles, hawks and an owl. Mammalia 56:145-150

Bardo L, Bird DM (2009) The use of captive American kestrels (Falco sparverius) as wildlife models: a review. J Raptor Res 43:345-364

Berny PJ, Buronfosse T, Buronfosse F, Lamarque F, Lorgue G (1997) Field evidence of secondary poisoning of foxes (Vulpes vulpes) and buzzards (Buteo buteo) by bromadiolone, a 4-year survey. Chemosphere 35:1817-1829

Brakes CR, Smith RH (2005) Exposure of non-target small mammals to rodenticides: short-term effects, recovery and implications for secondary poisoning. J Appl Ecol 42:118-128

CAEPA (California Environmental Protection Agency) Department of Pesticide Regulation (2013) Memorandum on second generation anticoagulant rodenticides. July 27, 2013, Sacramento, CA. http://www.cdpr.ca.gov/docs/registration/reevaluation/chemicals/ brodifacoum_final_assess.pdf Accessed 12 Sept 2014

Craighead JJ, Craighead FC Jr (1956) Hawks, owls and wildlife. The Stackpole Co. and The Wildlife Management Institute, Harrisburg, PA and Washington, DC

Duke GE, Evanson OA, Jegers A (1976) Meal to pellet intervals in 14 species of captive raptors. Comp Biochem Physiol 53A:1-6

Filipsson AF, Sand S, Nilsson J, Victorin K (2003) The benchmark dose method-review of available models, and recommendations for application in health risk assessment. Crit Rev Toxicol 33:505-542

Goodwin MA, Davis JF, Brown J (1992) Packed cell volume reference intervals to aid in the diagnosis of anemia and polycythemia in young broiler chickens. Avian Dis 36:440-443 
Health Canada (2012) New use restrictions for commercial class rodenticides in agricultural settings. http://bailsmen.rssing.com/ browser.php?indx $=1140614 \&$ item $=195$. Accessed 12 September 2014

Howald G, Donlan CJ, Galvan JP, Russell JC, Parkes J, Samaniego A, Wang Y, Veitch D, Genovesi P, Pascal M, Saunders A, Tershy B (2007) Invasive rodent eradication on islands. Conserv Biol 21:1258-1268

Hughes J, Sharp E, Taylor MJ, Melton L, Hartley G (2013) Monitoring agricultural rodenticide use and secondary exposure of raptors in Scotland. Ecotoxicology 22:974-984

Island Conservation (2012) Database of island invasive species eradications. Hosted by the IUNC SSC Invasive Species Specialist Group. http://eradicationsdb.fos.auckland.ac.nz/. Accessed 12 September 2014

Kaukeinin DE (1982) A review of the secondary poisoning hazard potential to wildlife from the use of anticoagulant rodenticides. Proc Vert Pest Conf 10:151-158

Kerins GM (1999) Plasma fibrinogen concentration is increased following depletion of vitamin K-dependent clotting factors by the indirect anticoagulant difenacoum in Norway rats (Rattus norvegicus). Comp Haematol Int 9:76-82

Luna LG (1968) Manual of histological staining methods of the Armed Forces Institute of Pathology, 3rd edn. McGraw Hill, New York

Mendenhall VM, Pank LF (1980) Secondary poisoning of owls by anticoagulant rodenticides. Wildl Soc Bull 8:311-315

Mosterd JJ, Thijssen HHW (1991) The long-term effects of the rodenticide, brodifacoum, on blood coagulation and vitamin $\mathrm{K}$ metabolism in rats. Br J Pharmacol 104:531-535

Motulsky H (2010) Intuitive biostatistics: a nonmathematical guide to statistical thinking, 2nd edn. Oxford University Press, New York

Murray M (2011) Anticoagulant rodenticide exposure and toxicosis in four species of birds of prey presented to a wildlife clinic in Massachusetts, 2006-2010. J Zoo Wildl Med 42:88-97

Nagy KA (1987) Field metabolic rate and food requirement scaling in mammals and birds. Ecol Monogr 57:111-128

Newton I, Shore RF, Wyllie I, Birks JDS, Dale L (1999) Empirical evidence of side-effects of rodenticides on some predatory birds and mammals. In: Cowan DP, Feare CJ (eds) Advances in vertebrate pest management. Filander Verlag, Furth, pp 347-367

Porter RD, Wiemeyer SN (1970) Propagation of captive American kestrels. J Wildl Manage 34:594-604

Primus TM, Eisemann JD, Matschke GH, Ramey C, Johnston JJ (2001) Chlorophacinone residues in rangeland rodents: an assessment of the potential risk of secondary toxicity to scavengers. In: Johnston JJ (ed) Pesticides and wildlife. ACS Symposium Series 771. American Chemical Society, Washington, DC, pp 164-180

Radvanyi A, Weaver P, Massari C, Bird D, Broughton E (1988) Effects of chlorophacinone on captive kestrels. Bull Environ Contam Toxicol 41:441-448

Ramey CA, Matschke GH, Engeman RM (2007) Chlorophacinone baiting for Belding's ground squirrels. Wildl Manage Damage Conf 12:526-537

Rattner BA, Horak KE, Warner SE, Johnston JJ (2010) Acute toxicity of diphacinone in Northern bobwhite: effects on survival and blood clotting. Ecotoxicol Environ Saf 73:1159-1164

Rattner BA, Horak KE, Warner SE, Day DD, Meteyer CU, Volker SF, Eisemann JD, Johnston JJ (2011) Acute toxicity, histopathology, and coagulopathy in American kestrels (Falco sparverius) following administration of the rodenticide diphacinone. Environ Toxicol Chem 30:1213-1222

Rattner BA, Horak KE, Lazarus RS, Eisenreich KM, Meteyer CU, Volker SF, Campton CM, Eisemann JD, Johnston JJ (2012a) Assessment of toxicity and potential risk of the anticoagulant rodenticide diphacinone using Eastern screech-owls (Megascops asio). Ecotoxicology 21:832-846

Rattner BA, Lazarus RS, Eisenreich KM, Horak KE, Volker SF, Campton CM, Eisemann JD, Meteyer CU, Johnston JJ (2012b) Comparative risk assessment of the first-generation anticoagulant rodenticide diphacinone to raptors. Proc Vert Pest Conf 25:124-130

Rattner BA, Horak KE, Lazarus RS, Goldade DA, Johnston JJ (2014a) Toxicokinetics and coagulopathy threshold of the rodenticide diphacinone in Eastern screech-owls (Megascops asio). Environ Toxicol Chem 33:74-81

Rattner BA, Lazarus RS, Elliott JE, Shore RF, van den Brink N (2014b) Adverse outcome pathway and risks of anticoagulant rodenticides to predatory wildlife. Environ Sci Technol 48:8433-8445

Rattner BA, Lazarus RS, Schultz SL, Horak KE, Abbo BG, Volker SF (2014c) Development of dietary-based toxicity reference values to assess the risk of chlorophacinone to non-target raptorial birds. Proc Vert Pest Conf 26, in press

Riedel B, Riedel M, Wieland H, Grün G (1988) Vogeltoxikologische bewertung des einsatzes von delicia-chlorphacinon-ködern in landwirtschaftlichen kulterun. Institut für Planzenschutzforshung Kleinmachnow der Akademie der Landwirtschaftwissenschaften der DRR 42:48-51

Salim H, Mohd Noor H, Hamid NH, Omar D, Kasim A, Abidin CMRZ (2014) Secondary poisoning of captive barn owls, Tyto alba javanica through feeding rats poisoned with chlorophacinone and bromadiolone. J Oil Palm Res 26:62-72

Savarie PJ, Hayes DJ, McBride RT, Roberts JD (1979) Efficacy and safety of diphacinone as a predacide. In Kenaga EE (ed) Avian and mammalian wildlife toxicology. STP 693 American Society for Testing Materials, Philadelphia, Pennsylvania, pp 69-79

Shlosberg A, Booth L (2006) Veterinary and clinical treatment of vertebrate pesticide poisoning - a technical review. Landcare Research, Lincoln, NZ

Stone WB, Okoniewski JC, Stedelin JR (1999) Poisoning of wildlife with anticoagulant rodenticides in New York. J Wildl Dis $35: 187-193$

Stone WB, Okoniewski JC, Stedelin JR (2003) Anticoagulant rodenticides and raptors: recent findings from New York, 1998-2001. Bull Environ Contam Toxicol 70:34-40

Sutcliffe FA, MacNicoll AD, Gibson GG (1987) Aspects of anticoagulant action: a review of the pharmacology, metabolism and toxicology of warfarin congeners. Rev Drug Metab Drug Interact 5:225-272

Thomas PJ, Mineau P, Shore RF, Champoux L, Martin PA, Wilson LK, Fitzgerald G, Elliott JE (2011) Second generation anticoagulant rodenticides in predatory birds: probabilistic characterization of toxic liver concentrations and implications for predatory bird populations in Canada. Environ Int 37:914-920; Corrigendum 40:256

US Environmental Protection Agency (2010) Risks of chlorophacinone use on black tailed prairie dogs to federally endangered and threatened species. http://www.epa.gov/espp/litstatus/effects/ chlorophacinone/assessment.pdf. Accessed 12 Sept 2014

US Environmental Protection Agency (2011a) Risks of non-compliant rodenticides to nontarget wildlife-Background paper for scientific advisory panel on notice of intent to cancel non-RMD compliant rodenticide products. http://www.regulations.gov/\#!documentDe tail;D=EPA-HQ-OPP-2011-0718-0006. Accessed 12 Sept 2014

US Environmental Protection Agency (2011b) Benchmark Dose Software (BMDS) Version 2.2 R65 [Build: 04/13/2011]. National Center for Environmental Assessment. http://www. epa.gov/NCEA/bmds/index.html. Accessed 12 Sept 2014

US Environmental Protection Agency (2012) Risk mitigation decision for ten rodenticides. http://www.epa.gov/pesticides/reregistra tion/rodenticides/finalriskdecision.htm Accessed 15 July 2011 
US Environmental Protection Agency (USEPA) (2000) Assigning values to non-detected/non-quantified pesticide residues in human health food exposure assessments. http://www.epa.gov/ oppfead1/trac/science/trac3b012.pdf. Accessed 12 Sept 2014

US Fish and Wildlife Service (USFWS) (2012) Final biological option for Rozol use on black-tailed prairie dogs registered under Section 3 of the Federal Insecticide, Fungicide and Rodenticide Act. http://www.epa.gov/espp/2012/borozol-final.pdf. Accessed 12 Sept 2014

Vandenbroucke V, Bousquet-Melou A, De Backer P, Croubels S (2008) Pharmacokinetics of eight anticoagulant rodenticides in mice after single oral administration. J Vet Pharmacol Ther 31:437-445
Vein J, Vey D, Fourel I, Berny P (2013) Bioaccumulation of chlorophacinone in strains of rats resistant to anticoagulants. Pest Manage Sci 69:397-402

Vyas NB, Rattner BA (2012) Critique on the use of the standardized avian acute oral toxicity test for first generation anticoagulant rodenticides. Human Ecol Risk Assess 18:1069-1077

Vyas NB, Hulse CS, Meteyer CU, Rice CP (2013) Evidence of songbird intoxication from Rozol ${ }^{\circledR}$ application at a black-tailed prairie dog colony. J Fish Wildl Manage 4:97-103

Wing L, Wing AH (1939) Food consumption of a sparrow hawk. Condor 41:168-170 